\title{
ANALISIS FAKTOR-FAKTOR YANG MEMPENGARUHI PENDAPATAN DAN KELAYAKAN USAHA AGROWISATA STRAWBERRY (Fragaria choiloensis L.) PETIK SENDIRI (Studi Kasus : Kabupaten Karo)
}

\author{
Muhammad Jufriansyah1, Gustami Harahap ${ }^{2 *}$, Mitra Musika Lubis ${ }^{3}$ \\ ${ }^{1}$ Agribisnis, Fakultas Pertanian, Universitas Medan Area, Indonesia
}

Diterima: Agustus 2019 Disetujui: Oktober 2019 Dipublish: Oktober 2019

*Coresponding Email: gustamianita26@gmail.com

\begin{abstract}
Abstrak
Tujuan penelitian ini adalah untuk mengetahui apa saja faktor yang mempengaruhi tingkat pendapatanpetani agrowisata strawberry petik sendiri, mengetahui harga pulang pokok usaha agrowisata strawberry petik sendiri dan mengetahui apakah usaha agrowisata strawberry petik sendiri sudah layak. Metode pengambilan sampel digunakan dengan cara metode Central limit theorem, jumlah populasi petani strawberry yang ada dikabupaten Karo adalah 60, dalam penelitian ini 30 petani dijadikan sampel yang cukup representative atas keseluruhan populasitersebut. Data yang dikumpulkan adalah data primer dan sekunder. Metode analisis yang digunakan adalah regresi linier berganda dengan alat bantu perangkat lunak SPSS 21, BEP dan analisis kelayakan usaha menggunakan R/C Ratio. Hasil penelitian ini adalah pendapatan petani strawberry berpengaruh positif terhadap volume penjualan dan pengeluaran RT. Analisis data dari (BEP) adalah sebesar Rp. 38.304.239 dengan volume penjualan sebesar 478,80 $\mathrm{Kg}$ dan harga jual $\mathrm{Rp}$. 52.760/Kg. Analisis kelayakan usaha agrowisata strawberry petik sendiri, di peroleh hasil $\mathrm{R} / \mathrm{C}>1$ maka secara ekonomi usaha tersebut layak dilaksanakan.
\end{abstract}

Kata Kunci : Pendapatan, Kelayakan Usaha, Strawberry (,).

\begin{abstract}
The purpose of this study was to find out what factors influence the level of income of strawberry picking agrotourism farmers themselves, knowing the price of their own picking strawberry agro-tourism business and knowing whether the picking strawberry agro-tourism business itself is feasible. The sampling method is used by the Central theorem limit method, the total population of strawberry farmers in Karo Regency is 60, in this study 30 farmers were made as representative samples of the entire population.The data collected is primary and secondary data. The analytical method used is multiple linear regression with SPSS 21, BEP software tools and business feasibility analysis using $R / C$ Ratio. The result this study are strawberry farmers' income have positive effect on sales and expenditure volume of RT. Analysis of data from (BEP), volume reaches the level of $478.80 \mathrm{Kg}$ with a selling priceof Rp.52,760 / Kg, then the sales result is Rp. 38,304,239, with the results of the sale,the strawberry picking agro-business itself was declared even. Analysis of the feasibility of the own strawberry picking agrotourism business obtained the results of $R / C>1$ then the business is economically feasible.
\end{abstract}

Key Words: Revenue, Business Feasibility, Strawberry (,)

How to Cite: Jufriansyah, M. Harahap, G., \& Lubis, M.M. 2019. ANALISIS FAKTOR-FAKTOR YANG MEMPENGARUHI PENDAPATAN DAN KELAYAKAN USAHA AGROWISATA STRAWBERRY (Fragaria choiloensis L.) PETIK SENDIRI (Studi Kasus : Kabupaten Karo). Jurnal Agriuma. 1(2): 78-89. 


\section{PENDAHULUAN}

Tanaman stroberi di Indonesia sebenarnya telah lama di tanam semenjak jaman penjajahan dahulu tetapi sampai saat ini penyebaran dan budidaya stroberi belum meluas ke daerah-daerah di seluruh Indonesia padahal tanaman lainnya seperti : komoditi jeruk, apel, dan anggur sudah berkembang. Manfaat stroberiselain sumber vitamin dan mineral untuk memenuhi kebutuhan gizi manusia juga mempunyai nilai ekonomi yang di perhitungkan (Soemadi,1997)

Di Sumatera Utara terdapat salah satu jenis tanaman hortikultura yang sesuai di daerah beriklim tropis yaitu stroberi, yang mana banyak dijumpai dan sudah cukup lama dibudidayakan dikabupaten KarokhususnyadiKecamatan Tiga Panah di Desa Tongkoh. Jenis tanaman ini mempunyai prospek yang cukup baik, ditinjau dari segi kemampuan produksi, tanaman ini dapat di panen 4 kali dalam setahun. Disamping itu untuk memenuhi kebutuhan pasar dalam penyediaan buah-buahan guna menunjang program parawisata. Minat masyarakat untuk menanam stroberi semakinmeningkat.

Diketahui bahwa pada tahun 2012 terjadi peningkatan produksi (ton) buah stroberi sebanyak 196.796 dari tahun - tahun sebelumnya, kemudian terjadi penurunan produksi setelah tahun - tahun berikutnya yakni pada tahun 2014 terjadi penurunan produksi sebanyak 58.882 ton buah stroberi. Adapun Permasalahan stroberi di Indonesia adalah ketersediaan benih berkualitas dan bebas penyakit. Penyediaan benih stroberi selama ini dilakukan secara konvensional dengan menggunakan stolon. Kelemahannya adalah volume perbanyakan relative lebih sedikit dan tidak bebas penyakit karena infeksi pathogen endogenous yang ditularkan dari tanaman induk. di Pulau Sumatera yang paling banyak memproduksi stroberi adalah Provinsi sumatera Utara dengan produksi 116 Ton pada luas lahan yaitu 21 Ha. Provinsi Sumatera Utara penghasil Stoberi terbanyak sesuai data pada tabel 2 diatas, salah satu kabupaten yang penyumbang produksi Stoberi terbesar untuk provinsi Sumatera Utara adalah KabupatenKaro.

Dapat diketahui bahwa pada tahun 2013 produksi stroberi itu sebanyak 482 ton dengan produktivitas 98,27 Kw/Ha pada luas lahan 25 Ha. Kemudian pada tahun selanjutnya yaitu 2014 terjadi penurunan hasil produksi stroberi sebanyak 104 ton dengan produktivitas 52,00 Kw/Hapada luas lahan 9 Ha.Pada tahun2017terjadi peningkatan produktivitas sebanyak $76,00 \mathrm{Kw} / \mathrm{Ha}$ dengan produksi sebanyak 266 ton pada luas lahan $15 \mathrm{Ha}$. 
Pengolahan usaha agrowisata stroberi petik sendiri sudah berlangsung selama 13 tahun sesuai data Dinas Pertanian Kabupaten Karo. Setelah pra-survei yang telah dilaksanakan masih sedikit jumlah petani yang mengusahakan tanaman stroberi. Namun harga jual stroberi cukup terbilang mahal dengan harga jual Rp.80.000/Kg.

\section{METODE PENELITIAN}

Penelitian ini dilakukan di Kabupaten Karo, Sumatera Utara dan Waktu penelitian dilaksanakan selama bulan Januari 2018 sampai bulan Maret 2018. Alasan penentuan dan penetapanlokasi penelitian karena kabupaten Karo merupakan satu-satunya sentral produksi tanaman stroberi yang ada di Sumatera Utara. Populasi dalam penelitian ini adalah petani yang mengusahakan strawberry petik sendiri yang ada di lokasi penelitian. Populasi sampel sebanyak 60 petani strawberry. Metode pengambilan sampel petani strawberry dilakukan dengan pengambilan sampel secara acak sederhana (Simple Random Sampling). Objek dalam penelitian ini adalah apa saja foktor yang mempengaruhi tingkat pendapatan petani agrowisata starawberry perik sendiri, berapakah harga pulang pokok usaha agrowisata strawberry petik sendiri, dan apakah usaha agrowisata strawberry petiksendiri sudah layak diusahakan. Metode analisisdata dalam penelitian ini menggunakan metode Analisis Regresi Berganda dan studi kelayakan usaha yaitu $\mathrm{R} / \mathrm{C}$ ratio sebagai berkut:

\section{Analisis Regresi Linier Berganda}

$$
\mathrm{Y}=\mathrm{b} 0+\mathrm{b} 1 \mathrm{X} 1+\mathrm{b} 2 \mathrm{X} 2+\mathrm{b} 3 \mathrm{X} 3+\mathrm{b} 4 \mathrm{X} 4+\mathrm{b} 5 \mathrm{X} 5+\mathrm{e}
$$

Ket : Y : Pendapatan petani (Rp/Bulan) b0 : konstan yang merupakan intersep garis antara X dengan Y, X1 : Luas lahan strowbery (Ha), X2 : Volumepenjualan(Kg/Bulan), X3: Harga jual (Rp/Bulan), X4 : Pengeluaran RT petani (Rp/Bulan), X5 : Pengalaman usaha (Tahun)

\section{Kelayakan Usaha dan BEP (Break EvenPoint)}

Perhitungan kelayakan usaha yang sering digunakan adalah Return Cost Rasio (R/C Ratio). Return cost ratio adalah perbandingan antara nisbah penerimaan dan biaya. Secara matematik, hal ini dapat dituliskan sebagai berikut:

$\mathrm{a}=(\mathrm{Py} \cdot \mathrm{Y}) /(\mathrm{FC}+\mathrm{VC})$

Ket $: \mathrm{a}=$ Pembanding (nisbah) antara penerimaan dan biaya, $\mathrm{R}=$ Penerimaan

$\mathrm{C}=$ Biaya, $\mathrm{Py}=$ Harga output, $\mathrm{Y}=$ output, $\mathrm{FC}=$ Biaya Tetap, $\mathrm{VC}=$ Biaya Variabel 
Menurut Soekartawi (2003), Kriteria Kelayakan adalah sebagai berikut :

1. Secara teoritis dengan rasio $\mathrm{R} / \mathrm{C}=1$ artinya tidak untung dan tidak pula rugi,dalam hal ini petani atau produsen dapat dikatakan mencapai titik impas atau Break Even Point(BEP)

2. $\mathrm{R} / \mathrm{C}<1$, maka usaha tidak layak untukdilaksanakan

3. $\mathrm{R} / \mathrm{C}>1$, maka usaha layak untukdilaksanakan

Penelitian ini menggunakan angket atau kuesioner sebagai instrument yang nantinya akan diisi oleh responden. Angket atau kuesioner berisi pertanyaan-pertanyaan yang bersifat terbuka dan tertutup, yaitu jawaban belum dan sudah disediakan oleh peneliti dan responden akan menjawabnya sesuai keadaan sebenarnya, selain itu untuk memperoleh informasi yang pasti dan lebih mendalam peneliti juga menggunakan teknik wawancara dengan responden secara langsung.

\section{HASIL DAN PEMBAHASAN}

\section{Analisis Regresi Linear Berganda}

Berdasarkan hasil perhitungan dengan menggunakan alat bantu SPSS 21, hasil yang diperoleh untuk perhitungan regresi linear berganda dari faktor-faktor yang mempengaruhi pendapatan usaha agrowisata strawberry petik sendiri di KabupatenKarodapatdilihatpada Tabel berikut:

Tabel 1. Hasil perhitungan dari Faktor-faktor yang mempengaruhi Pendapatan

Usaha Agrowisata Strawberry Petik Sendiri

\begin{tabular}{lccc}
\hline \multicolumn{1}{c}{ Variabel } & B & T-Hitung & Signifikan \\
\hline Konstanta & 51025765,78 & 1,282 & 0,212 \\
X1 = Luas Lahan & $-3435,082$ & $-8,897$ & 0,379 \\
X2 = Volume Penjualan & 673829,572 & 6,990 & 0,000 \\
X3 = Harga Jual & $-607,014$ & $-1,197$ & 0,243 \\
X4 = Pengeluaran RT & $-3,617$ & $-2,092$ & 0,047 \\
X5 = Pengalaman Usaha & $-701389,749$ & $-1,469$ & 0,155 \\
\hline
\end{tabular}

$$
\begin{aligned}
& \text { R-Square = 0,882 } \\
& \text { F-hitung }=36,033 \\
& \text { F-tabel }=2,261 \\
& \text { T-tabel }=2,064
\end{aligned}
$$

Sumber : Data Primer diolah 2018 
Berdasarkan tabel diatas hasil analisis regresi linier berganda maka adapun persamaan sebagai berikut:

$$
\begin{aligned}
& Y=b_{0}+b_{1} X_{1}+b_{2} X_{2}+b_{3} X_{3}+b_{4} X_{4}+b_{5} X_{5}+e \\
& Y=51025765,78-3435,082 X_{1}+673829,572 X_{2}-607,014 X_{3}-3,617 X_{4}-701389 X_{5}+ \\
& \text { Error }
\end{aligned}
$$

Berdasarkan persamaan tersebut dapat diketahui bahwa :

1. Konstanta $(\mathrm{a})=51025765,78$ menunjukan nilai konstanta, jika niai Luas Lahan (X1), VolumePenjualan (X2), HargaJual (X3), Pengeluaran RT (X4), dan Pengalaman Usaha (X4) = 0 maka pendapatan usaha agrowisata strawberry petik sendiri (Y) akan sebesar Rp.51.025.765,78

2. Koefisien regresi variabel Luas Lahan (X1) sebesar -3435,082 artinya jika Luas Lahan mengalami kenaikan luas sebesar $1 \mathrm{Ha}$ /Tahun, maka pendapatan usahaagrowisata strawberry petik sendiri akan mengalami penurunan sebesar Rp. 3.435,082 /Tahun.

3. Koefisien regresi variabel volume penjualan (X2) sebesar 673829,572 artinya jika volume penjualan mengalami kenaikan sebesar Rp. $1 \mathrm{~kg} /$ Bulan, maka pendapat usaha agrowisata strawberry petik sendiri akan mengalami peningkatan sebesar Rp. 673.829,572/Tahun.

4. Koefisien regresi variabel harga jual (X3) sebesar - 607,014 artinya jika harga jual mengalamikenaikan harga sebesar Rp. 1.000/Bulan, maka pendapatan usaha agrowisata strawberry petik sendiri akan mengalamipenurunan sebesar Rp. 607,014/Tahun.

5. Kofisien regresi variabel penegluaran RT (X4) sebesar -3,617artinya jika pengeluaran RT mengalami kenaikan harga Rp. 1.000/Bulan, maka pendapatan usaha agrowisata strawberry petik sendiri akan mengalami penurunan sebesar Rp.3,617/Bulan.

\section{Pembahasan}

1. Luas Lahan(X1)

Berdasarkan hasil uji statistic pada tingkat kepercayaan 95\% tingkat signifikansi (0,379 > 0,05) dapat disimpulkan bahwa tidak ada pengaruh yang nyata antara luas lahan dengan pendapatan usaha agrowisata strawberry petik sendiri.

Hal ini sejalan dengan teori yang dikemukakan oleh Soekartawi (2003), luas lahan pertanianakan mempengaruhi skala usaha yang pada akhirnya akan mempengaruhi efesien 
atau tidaknya suatu usaha pertanian. Sering kali dijumpai makin luas lahan yang dipakai dalam usaha pertanian semakin tidak efisien lahan tersebut. Ini didasarkanpadapemikiranbahwaluaslahan mengakibatkan upaya melakukan tindakan yang mengarah pada segi efesiensi akan berkurang karena:

1. Lemahnya pengawasan pada faktor produksi seperti bibit, pupuk, obat-obatan dan tenagakerja.

2. Terbatasnya persediaantenaga kerja disekitar daerah itu, yang pada akhirnya mempengaruhi efesiensi usaha pertaniantersebut.

3. Terbatasnya persediaan modal untuk membiayai usaha pertanian dalam skala luas tersebut.

Berdasarkan penelitian yang sayalakukan luas lahan tidakada pengaruh signifikan teradahap pendapatan usaha agrowisata strawberry petik sendiri dikarenakan semakin luasnya lahan strawberry belum tentu petani akan mendapatkan pendapatan yang tinggi. Begitu sebaliknya ketika luas lahan petani sedikit, bisa saja petaniakan mendapatkan pendapatan strawberry yang tinggi. Karenabiya produksi usaha agrowisata strawberry rata-rata sebesar $726 \mathrm{Kg} /$ tahun.

2. Volume penjualan (X2)

Berdasarkan hasil uji statistic pada tingkat kepercayaan 95\% tingkat signifikansi $(0,000<$ 0,05) dapat disimpulkan bahwa ada pengaruh yang nyata antara volume penjualan dengan pendapatan usaha agrowisata strawberry petiksendiri.

Hal ini sejalan dengan teori yang dikemukakan oleh Bashu Swastha DH (2008), yaitu volume penjualan merupakan jumlah total yang dihasilkan dari kegiatan penjualan barang. Semakin besar jumlah penjualan yang dihasilkan perusahaan, semakin besar kemungkinan laba yang akan dihasilkan perusahaan. Oleh karena itu volume penjualan salah satu hal penting yang harus dievaluasi untuk kemungkinan perusahaan agar tidak rugi.

Dari hasil penelitian yang saya lakukan dilapangan semakin banyaknya volume penjualan yang dilakukan oleh petani maka semakin banyak pula hasil pendapatan yang diterima oleh petani. Begitu pula sebaliknya ketika volume penjualan strawberry sedikit yang di lakukan oleh petani, maka sedikit pula hasil pendapatan yang petani dapatkan.

3. Harga jual(X3) 
Berdasar kan hasil uji statistic pada tingkat kepercayaan 95\% tingkat signifikansi (0,243 > 0,05) dapat di simpulkan bahwa tidak ada pengaruh yang nyata antara harga jual dengan pendapatan usaha agrowisata strawberry petiksendiri.

Hal ini tidak sejalan yang dikemukakan oleh teori Achmad (2002), menyatakan harga jual adalah jumlah uang yang bersedia di bayaroleh pembelidan bersedia diterima oleh penjual. Harga jual adalah nilai yang tercermin dalam daftar harga,harga eceran, dan harga adalah nilai akhir yang diterima oleh perusahaan sebagai pendapatan atau net price. Harga jual merupakan penjumlahan dari harga pokok barang yang dijual, biaya adminitrasi, biaya penjualan, serta keuntungan yangdiinginkan.

Berdasarkan dari hasil penelitian yang saya lakukan harga jual tidak berpengaruh terhadap pendapatan disebabkan jika jumlah pengunjung agrowisata strawberry petik sendiri banyak ataupun sedikit baik pada hari biasa atau weekend, petani strawberry tidak akan menaikan harga jual strawberry terhadap pengunjung/pembeli.

\section{Pengeluaran RT(X4)}

Berdasarkan hasil uji statistic pada tingkat kepercayaan 95\% tingkat signifikansi (0,047 < 0,05) dapat disimpulkan bahwa ada pengaruh yang nyata antara pengeluaran RT dengan pendapatan, tetapi hubungananya negatif karena pengeluaran RT lebih tinggi dari pada pendapatan usaha agrowisata strawberry petik sendiri.

Halini tidak sejalan dengan teori yang dikemukakan oleh Michael James (2001) yaitu konsumsi adalah semua penggunaan barang dan jasa yang dilakukan manusia untuk memenuhi kebutuhan hidupnya. Barang dan jasa yang di gunakan dalam proses produksi tidak termasuk konsumsi, karena barang dan jasa itu tidak digunakan untuk memenuhui kebutuhan hidup manusia. Barang dan jasa dalam proses produksi ini digunakan untuk memproduksi barang lain. Tindakan konsumsi dilakukan oleh siapa pun, tujuan nya adalah untuk memperoleh kepuasan setinggi-tinginya dan mencapai tingkat kemakmuran dalam arti terpenuhi berbagai macam kebutuhan, baik kebutuhan pokok maupun skunder, barang mewah maupun kebutuhan jasmani dan kebutuhanrohani. Untuk dapat mengkonsumsi, seseorang harus mempunyai pendapatan, besar kecilnya pendapatan seseorang sangat menentukan tingkat konsumsinya. Biasanya pertambahan pendapatan adalah lebih tinggi dari pada pertambahan konsumsi. Seharusnya peningkatan pengeluaran mereka sejalan dengan pendapatan mereka. 
Berdasarkan hasil penelitian yang saya dapat di lapangan dari beberapa wawancara kepada petani strawberry bahwa ada pengaruh pengeluaran RT terhadap pendapatan, karenapengeluaranRT disetiap petani berbeda-beda seperti fasilitas dirumah kemudian tanggungan keluarga dan kebutuhan sehari-hari yang dibutukan petani strawberry tiapharinya.

\section{Pengalaman usaha (X5)}

Berdasarkan hasil uji statistic pada tingkat kepercayaan 95\% tingkat signifikansi $(0,155>$ 0,05) dapat disimpulkan bahwa tidak ada pengaruh yang nyata antara pengalaman usaha dengan pendapatan usaha agrowisata strawberry petik sendiri.

Hal ini tidak sejalan dengan teori yang dikemukakan oleh Asmi (2008), yang menyatakan lama usaha merupakan suatu penentu cari pendapatan, khususnya pada sector informal. Lama usaha merupakan waktu yang sudah dijalani pengusaha dalam menjalankan usahanya. Lama usaha menentukan, semakin lama usaha maka akan semakin baik kualitas usahatersebut.

Dari hasil penelitian yang telah saya lakukan dilapangan bahwa rata - rata pengalaman usaha 5 sampai 13 tahun sebanyak 22 petani. Hal ini disebabkan karena seluruh petani strawberry menyatakan bahwa kurangnya penyuluhan pertanian dari pemerintah Kabupaten Karo mengenai pembudidayaan strawberry serta cara meningkatkan produksi strawberry itu sendiri. Jadi petani tidak mampu mengadopsi

inovasi baru untuk meningkatkan produksi strawberry tersebut, maka dari itu lamanya pengalaman usaha tidak mempengaruhi pendapatan petani.

\section{Analisis harga pulang pokok}

Berdasarkan hasil analisis data, rata-rata biaya variabel(AVC), yang diperoleh dari hasil bagi total biaya variabel (TVC) dengan total produksi rata - rata 726 Kg/Tahun dengan penjualan sebesar Rp. 58.080.000, maka di peroleh rata - rata biaya variabel (AVC) sebesar Rp. 35.611.333 dan biaya tetap (TFC) sebesar Rp. 2.719.601 sedangkan rata - rata harga penjualan strawberry sebesar Rp.80.000/Kg. Berdasarkan data tersebut, harga pulang pokok usaha agrowisata strawberry petik sendiri dapat diketahui bahwa biaya tetap total ialah Rp. 2.719.601. biaya variabel ialah 60\% dari penjualan, sedangkan hasil penjualan total ialah Rp. 58.080.000.

Dari perhitungan diatas dapat diketahui bahwa pada volume penjualan $\quad$ strawberry $R p$. 38.304.239, tidak rugi dan tidak laba disebut BE. Karena harga jual adalah tetap sama sajaper kilogram, maka jika harga jual per kilogram juga diketahui, akan diketahui pula kuantitasnya dengan cara membagi hasil penjualan strawberry Rp. 38.304.239, itu dengan harga jual per 
kilogram strawberry. Harga jual per kilogram strawberry ialah Rp. 80.000, maka kuantitas yang dijual ialah 478,80 Kg. Kemudian harga pulang pokok per kilogramnya dapat diketahui dari hasil penjualan strawberry yang tidak untung dan tidak rugi yaitu sebesar Rp. 38.304.239 dibagi jumlah rata - rata total produksi sebanyak $726 \mathrm{Kg}$. Maka hasil harga pulang pokok per kilogram strawberry adalah sebesar Rp. 52.760-,

Dapat digambarkan suatu grafik yang didalam nya BE akan dapat diketahui sekaligus jumla rupiah dari hasil penjualan, kuantita yang dijual, biaya variabel, biaya tetap, laba marjinal, laba pada tingkat penjualan tertentu, kerugian pada tingkat penjualan tertentu, dan titik BE.

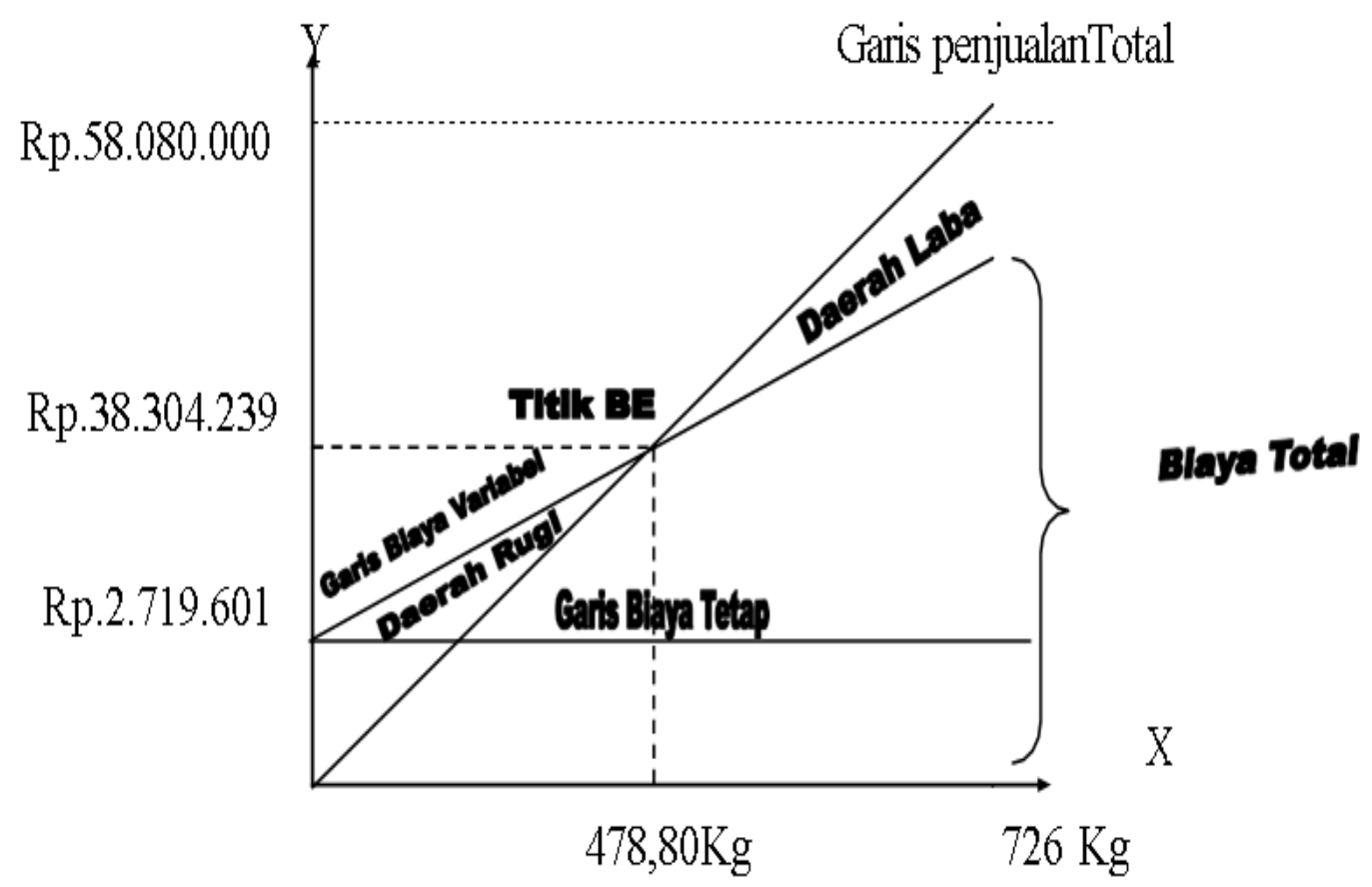

Gambar 1 grafik perpotongan pada posisi Titik Harga Pulang Pokok Usaha Agrowisata Strawberry Petik Sendiri Kabupaten Karo

a. Garis vertikal yang disebut sumbuh $\mathrm{Y}$ adalah garis yang menunjukan biaya dan juga hasil penjualan total dalam rupiah

b. Garis alas atau garis horizontal paling bawah disebut sumbuh $\mathrm{X}$ menunjukkan kuantita yang dijual, juga menunjukkan kapasitas/kuantitaproduk. (karena harga jual per kilogram akan tetapsama, maka garis ini sekaligus juga dapat digunakan untuk menunjukkan penjualan dalam rupiah).

c. Biaya tetap sebesar Rp. 2.719.601, digambarkan oleh garis mendatar sejajar garis alas. (dalam contoh lain garis biaya tetap dapat digambar sejajar dengan garis biayatotal, 
dimulai dari titik nol). Dalam gambar kurva diatas garis tetap ditarik kekanan dari angka Rp. 2.719.000

d. Dalam kurva tersebut usaha strawberry berkapasitas 100\% dengan kemampuan ratarataproduksi $726 \mathrm{Kg} /$ Tahun.Berarti pula penjualan dengan kapasitas itu maksimum Rp.58.080.000. oleh sebab itu garis penjualan adalah garis diagonal ditarik kekanan keatas dari titiknol ke titikangka Rp. 58.080.000, pad garis vertikal di sebelahkanan.

e. Persilangan antara garis biaya total dan garis penjualan total terjadi pada suatu titik. Titik ini lah yang disebut titik BE atau dalam bahasa asing disebut break even point. Dari titik itu ditarik garis vertical kebawah tegak lurus akan menunjukkan tingginya hasil penjualan yaitu Rp. 38.304.239, dan tinggnya biaya total juga sebesar Rp. 38.304.239. angka Rp.38.304.239,itu dapat diketahui dengan menarik garis horizontal ke kiri, sedangkan dengan garis vertikal ke bawah akan menunjukkan angka 478,80 yang berarti pada titik break even itu kuantita yang dijual(diproduksi) ialah sebanyak 478,80 $\mathrm{Kg}$.

\section{Analisis Kelayakan Usaha Agrowisata Strawberry Petik Sendiri Biaya Tetap (FC)}

Biaya tetap adalah biaya yang relative jumlahnya dan terus dikeluarkan walaupun produksi yang diperoleh sedikit atau banyak. Biaya tetap meliputi : Air dan Listrik. Berdasarkan data yang sudah ada, bahwa besarnya biaya tetap yang harus dikeluarkan petani strawberry di Kabupaten Karo yaitu sebesar Rp. 2.719.601. Biaya tersebut terdiri atas biaya penyusutan alat sebesar Rp. 1.445.769. Biaya air sebesar Rp. 188.333 yang dijumlahkan dari bulan pertama sampai bulan ke 12, serta besarnya biaya listrikyaitu Rp. 1.085.499

\section{Biaya Variabel (VC)}

Biaya variable adalah biaya yang dipengaruhi oleh besar kecilnya volume penjualan. Biaya variabel yang digunakan dalam proses produksi usaha agrowisata strawberry petik sendiri yaitu besarnya biaya variabel yang harus dikeluarkan petani strawberry di Kabupaten Karo yaitu sebesar Rp. 35.611.333. Biaya tersebut terdiri dari atas biaya penggunaan bibit sebesar Rp. 3.623.333, biaya penggunaan pupuk sebesar Rp. 1.399.000, biaya penggunaan pestisida sebesar Rp.1.260.000, dan biayatenagakerja sebesar Rp.29.654.000. Total biaya usaha agrowisata strawberry petiksendiri di Kabupaten Karo dapat yang harus dikeluarkan petani strawberry di Kabupaten Karo yaitu sebesar Rp. 38.330.934. Biaya tersebut diperoleh dari penjumlahan biaya tetap dan biaya variabel.

Penerimaan(TR) 
Penerimaan merupakan jumlah seluruh rata - ratap roduksi perkilogram strawberry di kali dengan harga jual per kilogram strawberry sebesar Rp.80.000. Bahwa penerimaan usaha agrowisata strawberry petik sendiri dalam satu tahun yaitu sebesar Rp.58.080.000 dengan jumlah produksi $726 \mathrm{Kg}$ dalam satu tahun.

\section{Analisi keuntungan}

Besarnya penerimaan usaha agrowisata strawberry petik sendiri dalam satu tahun ratarata 726 Kgbuahstrawberry.Usaha agrowisata strawberry petik sendiri akan memperoleh penerimaan sebesar Rp. 58.080.000, dengan jumlah rata - rata produksi setahun sebanyak 726 Kg dengan harga jual sebesar Rp. 80.000 per Kilogram.(data harga tahun2017)

Keuntungan diperoleh usaha agrowisata strawberry petik sendiri merupakan selisih antara penerimaan yang diterima dengan total biaya yang digunakan untuk proses produksi usaha agrowisata strawberry petiksendiri. Rincian biaya tersebut dapat dilihat secara lengkap pada tabel berikut ini:

Tabel 2. Rincian Rata - rata Biaya Keseluruhan Penerimaan dan Keuntungan

Usaha Agrowisata Strawberry Petik Sendiri selama 1 Tahun (2018)

\begin{tabular}{|c|c|c|c|}
\hline No & Jenis Biaya & $\begin{array}{c}\text { Nilai (Rp/0,3 } \\
\text { Ha) }\end{array}$ & $\begin{array}{c}\text { Nilai } \\
\text { Rp/Thn/ } \\
\text { Ha }\end{array}$ \\
\hline 1 & Penyusutan Alat & 1.445 .769 & 4.819 .230 \\
\hline 2 & Air & 188.333 & 627.776 \\
\hline 3 & Listrik & 1.085 .499 & 4.951 .663 \\
\hline \multicolumn{2}{|c|}{ Jumlah Biaya Tetap } & 2.719 .601 & 10.398 .669 \\
\hline No & Jenis BiayaVariabel & $\begin{array}{c}\text { Nilai } \\
\text { (Rp/Tahun) }\end{array}$ & $\begin{array}{c}\text { Nilai } \\
\text { Rp/Thn/ } \\
\text { Ha }\end{array}$ \\
\hline 1 & Bibit & 3.623 .333 & 12.077 .776 \\
\hline 2 & Pupuk & 1.399 .000 & 4.663 .333 \\
\hline 3 & Pestisida & 935.000 & 3.116 .666 \\
\hline 4 & Tenaga Kerja & 29.654 .000 & 98.846 .666 \\
\hline \multicolumn{2}{|c|}{ Jumlah Biaya Variabel } & 35.611 .333 & 118.704 .441 \\
\hline No & Uraian & Per tahun & $1 \mathrm{Ha} / \mathrm{Thn}$ \\
\hline 1 & Rata-rata Jumlah Produksi(Kg) & 726 & 2.420 \\
\hline 2 & Harga Jual/Kg & 80.000 & 80.000 \\
\hline TC $(\mathrm{T}$ & Biaya) & 38.330 .934 & 129.103 .110 \\
\hline TR (P & (imaan) & 58.080 .000 & 193.600 .000 \\
\hline Keun & an (TR-TC) & 19.749 .066 & 64.496 .890 \\
\hline
\end{tabular}

Sumber : Data Primer diolah peneliti, 2018 


\section{Rasio Penerimaan dan Biaya (R/C Ratio)}

R/C Ratio didapat dari hasil pembagi Total Reveniu (TR) dengan Total Biaya (TC) R/C Ratio $=\mathrm{TR} / \mathrm{TC}$

$$
\begin{aligned}
& =\text { Rp. } 58 \cdot 080.000 / \text { Rp. } 38 \cdot 330 \cdot 934 \\
& =1,515
\end{aligned}
$$

Dari perhitungan diatas tersebut, Usaha agrowisata strawberry petik sendiri layak untuk di usahakan. Karena R/C Ratio = 1,515 > 1Layak.

\section{SIMPULAN}

Hasil dari Penelitian yang menggunakan alat analisis regresi linier berganda diketahui yang berpengaruh positive terhadap pendapatan petani strawberry yaitu volume penjualan dan pengeluaran RT. Hasil analisis data dari harga pulang pokok (BEP) , diketahui bahwa, jika volume penjualan mencapai tingkat 478,80 Kg dengan harga jual Rp. 52.760/Kg, maka didapatkanhasil penjualan sebesar Rp.38.304.239, dengan hasil penjualan tersebut usaha agrowisata strawberry petik sendiri dinyatakan impas. Analisis kelayakan usaha agrowisata strawberry petik sendiri di Kabupaten Karo, di peroleh hasil $\mathrm{R} / \mathrm{C}>1$, maka secara ekonomi usaha tersebut layak dilaksanakan.

\section{DAFTAR PUSTAKA}

Achmad Slamet, 2002, Pengaruh Perkiraan Biaya Produksi dan Laba yang diinginkan terhadap Harga Jual Pada Industri Kecil Ganteng pres, Jurnal Ekonomi dan Manajemen, Dinamika, Vol. 11, 2, Hal.51.

Asmi,2008.Analisis Faktor - factor yang mempengaruhi Tingkat Pendapatan Pedagang Pasar Tradisional Di Kota Yogyakarta. Jurnal NeO - Bis. Universitas Bhayangkara. Vol. 2, pp, 197 -210

DH. Swastha, Iman Romansyah. 2016. "Analisis Penetapan Hargga Jual Produk Terhadap VolumePenjualan DalamPerspektif Ekonomi Islam”. Skripsi. Fakultas Ekonomi Dan Bisnis Islam Institut Agama Islam Negeri Raden Intan,Lampung.

Jafkar, dan Kamir. (2010). Analisis Kelayakan UsahaMobile Carwash Di Kota Bandung. Jurnal Online Institile Teknologi Nasional. Vol. 01, No 03. ISSN :2338-5081

Mahyu Danil, "Pengaruh Pendapatan Terhadap Tingkat Konsumsi Pada Pegawai Negeri Sipil Di KantorKabupatenBireuen”,Jurnal Ekonomika Universitas Almuslim Bireun Aceh (2013), Vol. IV No.7:9 Soemadi W. 1997. Stroberi dipot dan Kebun. Aneka. Yogyakarta Soekartawi. 2003. Prinsip Ekonomi Pertanian. Raja Grafindo Persada: Jakarta 